\title{
In reply: Please stop using nitrous oxide in routine clinical practice (comment on: Use of nitrous oxide in contemporary anesthesia-an ongoing tug of war)
}

\author{
Chee Sam Chan, BSc $\cdot$ Matthew T. V. Chan, MBBS, PhD
}

Received: 18 October 2021/Revised: 18 October 2021/ Accepted: 18 October 2021/Published online: 8 November 2021

(C) Canadian Anesthesiologists' Society 2021

\section{To the Editor,}

We thank Drs Hönemann and Kim for their interest in our editorial. ${ }^{1,2}$ As global citizens, we agree completely that all anesthesiologists should work together to reduce waste production and mitigate the effects of climate change. Drs Hönemann and Kim suggest abandoning the use of nitrous oxide to protect the environment. ${ }^{3,4} \mathrm{We}$ believe this recommendation should be weighed against the available alternatives. Without nitrous oxide, larger doses of fluorinated gases will have to be administered to maintain adequate anesthesia. These are also greenhouse gases and may produce similar environmental challenges if not adequately scavenged. ${ }^{5}$ For those who wish to swap to intravenous anesthesia, additional plastic syringes, tubings, and electricity to drive the infusion pumps may add to the environmental crisis. Furthermore, remifentanil has been shown to induce $\mu$-opioid receptor internalization and may contribute to acute postoperative opioid tolerance. ${ }^{6 .}$ In this respect, the potential role of nitrous oxide in preventing chronic postsurgical pain among select groups of patients should not be overlooked. Nevertheless, low-flow breathing systems, efficient scavenging, and closed filling should always be considered to avoid spilling waste anesthetic gases into the atmosphere. ${ }^{5}$

Disclosures None.

Funding statement None.
Editorial responsibility This submission was handled by Dr. Stephan K.W. Schwarz, Editor-in-Chief, Canadian Journal of Anesthesia/Journal canadien d'anesthésie.

\section{References}

1. Hönemann $C$, Kim SC. Please stop using nitrous oxide in routine clinical practice (comment on: Use of nitrous oxide in contemporary anesthesia - an ongoing tug of war). Can J Anesth 2022. https://doi.org/10.1007/s12630-021-02136-6

2. Chan CS, Chan MT. Use of nitrous oxide in contemporary anesthesia - an ongoing tug of war. Can J Anesth 2021; DOI: https://doi.org/10.1007/s12630-021-02094-z.

3. Sneyd JR, Montgomery H, Pencheon D. The anaesthetist and the environment. Anaesthesia 2010; 65: 435-7.

4. Griffiths J, Hill A, Spiby J, Gill M, Stott R. Ten practical actions for doctors to combat climate change. BMJ 2008; DOI: https://doi.org/ 10.1136/bmj.39617.642720.59.

5. Varughese $S$, Ahmed $R$. Environmental and occupational considerations of anesthesia: a narrative review and update. Anesth Analg 2021; 133: 826-35.

6. Ho IH, Ng LH, Cheng X, et al. Annexin A2 traps mu-opioid receptors in recycling endosomes upon remifentanil-induced internalization. Neurobiol Pain 2021; DOI: https://doi.org/10. 1016/j.ynpai.2021.100071.

Publisher's Note Springer Nature remains neutral with regard to jurisdictional claims in published maps and institutional affiliations.

C. S. Chan, BSc - M. T. V. Chan, MBBS, PhD ( $₫)$.

Department of Anaesthesia and Intensive Care, The Chinese

University of Hong Kong, Hong Kong Special Administrative

Region, China

e-mail: mtvchan@cuhk.edu.hk 